\title{
Alternative Methods in the Management of Menopausal Symptoms
}

\author{
Mehtap Gümüşay ${ }^{1}$, Nülüfer Erbil ${ }^{1}$ \\ ${ }^{1}$ Department of Gynecologic and Obstetric Nursing, Department of Nursing, Faculty of Health Sciences, Ordu University, \\ Ordu/Turkey
}

Received: 10 April 2016 Accepted: 28 June 2016, Published online: 25 August 2016

(C) Ordu University Institute of Health Sciences, Turkey, 2016

\begin{abstract}
The majority of women have mild or moderate symptoms during menopause, however, some women have severe complaints. Studies have been carried out which suggested that alternative methods are thought to be effective in improving menopausal symptoms. The aim of this review is to examine alternative methods used towards menopause symptoms using original research studies.

Published literatures and compurterised studies in Google Scholar, PubMed and Science Direct databases investigating effective methods at coping with menopause symptoms using the search terms "menopausal symptoms", "alternative methods", "management of symptoms" have examined in this study.

Studies have shown that acupuncture therapy can significantly reduce severity of hot flashes and it can improve sleep quality; moderate physical activity can reduce the frequency of hot flashes; the consumption of soy products can improve in vasomotor symptoms; probiotics can improve vaginal flora; an adequate intake of vitamin $\mathrm{D}$ and calcium during menopause may reduce the incidence of fractures.

Adapting healthy lifestyle behaviors and learning ways to reduce during the climacteric can help women adjust too many of the changes during this time. Health staffs should have inform about alternative methods and they should collect data with the use of alternative methods among women who menopausal symptoms.
\end{abstract}

Key words: Menopausal symptoms, Alternative methods, Management of symptoms.

\section{Address for correspondence/reprints:}

\section{Mehtap Gümüşay}

Telephone number: +90 45223450 10-5536

E-mail: mehtapgumusay@odu.edu.tr

\section{DOI: $10.19127 / \mathrm{mbsjohs.20236}$}

This study was submitted as poster presentation in 15th National Nursing Congress, 10-12 September 2015, Erzurum Turkey.

\section{Introduction}

Women's lives encompass six stages including infancy, childhood, puberty, sexual maturity, menopause and old age. The process of menopause, also known as the climacteric, begins around the age of 45 and continues an average of 15-20 years. These years include premenopause, perimenopause, postmenopause and senium, the final period of a woman's life span. During this time the production of female hormones declines, reproductive capacity gradually ceases, and certain symptoms and irregular menses begin to occur (Özkan, 2008; Egelioğlu, 2012).

Perimenopause includes the two to seven-year period before the onset of menopause and the oneyear amenorrhea period indicating that a woman has reached full menopause. Vasomotor changes, 
fatigue, headaches and emotional disturbances occur during this period. Postmenopause is defined as the period after menopause (Atasü\&Şahmay, 2001).

Various factors can affect the age of menopause onset. Heredity and race are most important. A study which examined the relationship between age at menarche and age at menopause found no statistically significant meaning (Oteroa et al., 2010). The age at menopause in European societies is between 45-54 years, while the average age of menopause in the United States is 51. Studies conducted in Turkey have determined that the average age of menopause is 47 for Turkish women (Özcan\&Oskay, 2013).

The majority of women have mild or moderate symptoms during menopause; however, some women have severe complaints. These changes and symptoms including vasomotor changes, emotional changes, sleep problems, changes in the urogenital system problems, muskular and skeletal problems and cardiovascular problems occur as a result of estrogen decline and they manifest as cycle disorders (Taşkın, 2012). Studies have been carried out which suggested that alternative methods are thought to be effective in improving menopausal symptoms (Al-Akoum et al., 2009; Mansikkamaki et al., 2012; Hachul et al., 2012; Taavoni et al., 2013; Newton et al., 2014).

The aim of this review is to examine alternative methods used towards menopause symptoms using original research studies.

\section{Method}

Published literatures and compurterised studies in Google scholar, PubMed and Science Direct databases investigating effective methods at coping with menopause symptoms using the search terms "menopausal symptoms", "alternative methods", "management of symptoms" have examined in this study.

\section{Vasomotor Changes}

Many menopausal women experience "hot flashes" and "night sweats" caused by changes in vasodilation and vasoconstriction.

Vasomotor changes may continue for 10 years after menopause. Hot flashes, which usually last between 30 seconds and 5 minutes, can 1-2 times or up to 50 times per day. These may disappear in six months or they may continue as long as 30 years. Seventy-five percent of women experience hot flashes during menopause. Hot flashes usually begin in the early stages of menopause. They vary in terms of frequency, duration and intensity and can spontaneously come to an end (Taşkın, 2012).

Although vasomotor symptoms are the most common and disturbing changes among the menopausal symptoms, the incidence varies among communities. Vasomotor symptoms are seen more often in European women than in those of Far East countries (Taşkın, 2012). A study in Turkey found that $65.1 \%$ of women experienced hot flashes and $41.9 \%$ were bothered by night sweats (Saka et al., 2005). Özvarış et al. (2014) determined that $67.9 \%$ of women complained of hot flashes, Chedraui et al. (2014) found that $77.6 \%$ of women have exposed hot flash, and Ertem (2010) found that $79 \%$ of women experienced hot flashes.

Studies have been carried out which suggested that certain plants are thought to be effective in easing menopausal symptoms. Carmignani et al. (2010) investigated the effect of the consumption of soy products, hormone therapy, and the placebo effect on menopausal symptoms. They determined a statistically significant improvement in vasomotor symptoms in the groups using soy products and hormone therapy. Another study found a reduction in vasomotor symptoms in women who consumed black cohosh tablets every day for 8 weeks, compared with women consuming a placebo (Mohammad-Alizadeh-Charandabi et al., 2013). A randomized controlled trial by Aghamiri et al. (2015) determined that hops (Humuluslupulus L) reduced the severity of menopausal symptoms.

Acupuncture studies have shown that this therapy can also reduce hot flashes. In a randomized controlled trial study, Nir et al. (2007) reported that when compared with acupuncture, a placebo was effective in reducing the severity of hot flashes. However, it was not effective in reducing their frequency. Another study determined that acupuncture had a statistically significant effect on the severity and frequency of hot flashes (Borud et al., 2009).

A study investigating the effect of physical activity on vasomotor symptoms reported that 50 minutes of exercise four times per week for six months caused a statistically meaningful decrease in the frequency of hot flashes (Luoto et al., 2012). Another study determined that moderate physical activity reduced the frequency of hot flashes (Elavsky, 2012). 


\section{Emotional Changes}

Menopausal changes affect a woman's body and brain function, and these often lead to physical and emotional changes (Kavlak, 2011). Many women going through menopause may experience fatigue, exhaustion and a general feeling of unhappiness. They may also have outbursts of temper, crying, memory lapses and an inability to concentrate (Taşkın, 2012). Koç and Sağlam's research (2008), determined that $82 \%$ of women experienced restlessness and irritability, $80.2 \%$ were forgetful, and $69.4 \%$ felt sad and depressed in the climacteric period. Another study determined that $40.0 \%$ of women felt nervous (Erkin et al., 2014). The relationship between depressive symptoms and estrogen has not been fully determined. Although some studies have reported that the decline of estrogen leads to depression, different results have also been reported (Bezircioğlu et al., 2004). These results have indicated that menopausal and depressive symptoms were affected by various cultural and ethnic factors (Taşkın, 2012).

The Baksu et al. (2005) study determined that when compared to a placebo, tibolone and transdermal estrogen helped improve menopausal symptoms, depression and anxiety. Another study reported that leaf of Ginkgo biloba increased mental flexibility (Borelli\& Ernst, 2010).

\section{Sleep Problems}

With increasing age, sleep problems become more prevalent in both genders. Some studies have indicated that perhaps the lack of estrogen affects women's REM sleep but this is controversial.

One study reported that $50 \%$ of menopausal women experienced insomnia (Saka et al., 2005). Another study determined that $35.3 \%$ of women suffered from insomnia (Erkin et al., 2014). Young et al. (2003) indicated that sleep quality wasn't worse in perimenopusal or postmenopausal women, compared with premenopausal; to the contrary, postmenopausal women had deep sleep and significantly longer total sleep time. Also, they found menopasusal status was moderately related to self-reported dissatisfaction with sleep but wasn't consistently associated with symptoms of insomnia or sleepiness (Young et al., 2003). Sleep disorders and sleep disruptions lead to irritability, anxiety, fatigue, forgetfulness, and concentration disorders in postmenopausal women (Saka et al., 2005; Kal, 2011).

In the studies noted that methods such medicinal herbs, acupuncture and exercises are used to improve sleep disorders (Taavoni et al., 2013; AlAkoum et al., 2009; Mansikkamaki et al., 2012; Hachul et al., 2012; Newton et al., 2014). Several studies determined a significant improvement in sleep quality for women who had taken part in regular aerobic exercise for six months (Mansikkamaki et al., 2012; Newton et al., 2014). Participation in yoga exercises also resulted in a statistically significant decrease in insomnia symptoms (Mansikkamaki et al., 2012; Newton et al., 2014). In a study of sleep disorders in which 100 women participated, $50 \%$ of the women consumed a

placebo capsule while the other $50 \%$ took a valerian and lemon balm capsule (Taavoni et al., 2013). Compared with the placebo, the valerian and lemon balm capsule had a definite effect on easing sleep disorders and improving women's quality of sleep (Taavoni et al., 2013). A study of Hypericumperforatum (St. John's Wort) and a placebo showed that this medicinal herb exerted a statistically significant improvement on women's sleep problems (Al-Akoum et al., 2009). In the Hachul et al. study (2012), acupuncture was applied to postmenopausal women who were not receiving any treatment. Results of the treatment showed a significant improvement in the women's quality of sleep and quality of life.

\section{Changes in the Urogenital System}

The onset of menopause also triggers many changes in a woman's urogenital system. These changes include a decrease in cervical and superficial glands' secretions, a thinning of the vaginal epithelium, and a decrease in elasticity and blood flow. The result is atrophic vaginitis. Vulvar dystrophy worsens. Genital atrophy during menopause creates dyspareunia, difficult or painful sexual intercourse, which has a negative impact on sexual function (Özkan, 2008; Taşkın, 2012).

Another change occurs with a thinning of the mucosa of the urethra and surrounding tissues. This affects the capacity of the bladder to retain urine. Consequently, women experience problems such as dysuria, urinary incontinence, and frequent urination. A study performed in our country found that two of five women experience sexual problems, vaginal dryness and urinary incontinence in the postmenopausal period (Özvarış et al., 2014). Another study found that $36.7 \%$ of women had sexual intercourse less often and $34.7 \%$ had less 
interest in sexual relations (Erkin et al., 2014). Many studies have been conducted to test the effectiveness of possible remedies to relieve the effects of menopausal changes. One study determined that two weeks of daily use of probiotics improved the vaginal flora (Petricevic et al., 2008). Another study reported that the use of hops brought about a statistically significant decrease in vaginal dryness (Borelli\&Ernst, 2010). The randomized controlled trial study of Larmo et al. (2014) determined that compared to the placebo, the intake of Buckthorn oil statistically significantly improved the integrity of the vaginal epithelium.

\section{Muscular and Skeletal Problems}

Bone loss begins after the age of 25-30 and accelerates after menopause due to decreasing estrogen levels. Approximately $30 \%$ of total body bone mass is lost in the first 15-20 years of the postmenopausal period. While $52-66 \%$ of this bone loss is due to loss of estrogen, the rest is due to the aging process (Kal, 2011).

Risk factors for osteoporosis in women are affected by genetic characteristics such as fair skin, short stature, and thin body frame. Other factors include lifestyle, eating habits, endocrine disease, and age at onset of menopause. The bone mineral density of darker races is higher than Caucasians. Bone degeneration caused by inactivity is a risk factor for osteoporosis. The use of tobacco and excessive alcohol consumption also contribute to its development (Taşkın, 2012). Studies have reported that the risk of osteoporosis for women in the United States over the age of 50 was $30.3 \%, 40.8 \%$ in Denmark, $35.4 \%$ in Japan and $24.9 \%$ in Switzerland (Kutlu et al., 2012). One study determined that $30.7 \%$ of women had joint pain (Erkin et al., 2014). Another study found that pain $(88.5 \%)$ is most common menopause symptom (Chedraui et al., 2014).

Isoflavones are estrogen-like substances which are found in plants and soy beans. Some studies suggest that the use of isoflavone may prevent the loss of bone minerals (Turhan et al., 2008). Isoflavones are also believed to reduce hot flashes and the risk of breast cancer (Borelli\&Ernst, 2010).

Since bone mineral density is correlated with vitamin A levels in the body, the intake of this vitamin has been found to reduce the risk of fractures (Jackson \& Sheehan, 2005). Furthermore, another study has shown that an adequate intake of vitamin $\mathrm{D}$ and calcium during menopause may reduce the incidence of fractures. The use of vitamin $\mathrm{K}$ is also believed to increase bone strength (Borelli \& Ernst, 2010; Papadimitropoulos et al., 2002; Richy et al., 2005).

\section{Cardiovascular Problems}

When compared to men of the same age, premenopausal women have 2.5-4.5 times less risk of developing cardiovascular disease (Kavlak, 2011). However, changes in lipid metabolism during the postmenopausal period have been reported to increase a woman's risk of cardiovascular diseases. These changes include decreases in the serum high-density lipoprotein (HDL) levels and increased levels of low-density lipoprotein (LDL) caused by cholesterol accumulation in the arteries. The increase in total cholesterol is a major risk factor for coronary heart disease (Taşkın, 2012).

As has been noted, the onset of menopause causes many changes in a woman's body and emotional status. These uncomfortable and sometimes disturbing changes have resulted in the proliferation of many alternative methods to relieve and manage the effects of menopausal symptoms. For example, studies have reported that long-term consumption of soy protein significantly decreases diastolic blood pressure and serum LDL levels, and isoflavone extract is also believed to reduce systolic blood pressure. These methods were found to have a positive impact on women's lives during the period of menopause but more evidence-based studies are needed (Borelli\&Ernst, 2010).

\section{Conclusion}

In conclusion, health professionals play a very important role helping to women, adapting healthy lifestyle behaviors and learning ways to reduce during the climacteric can help to women adjust to many of the changes during this time. Furthermore, women's menopausal symptoms and quality of life may improve by using alternative treatments which have been determined to be effective with evidence-based studies. Health professionals can offer recommendations on the consumption of soy, using black cohosh tablets, using acupuncture therapy, increasing physical activity, and increasing the consumption of probiotics and prebiotics and using vitamins. All of these measures, which would include developing positive and trusting relationships between women in menopause and their medical team, will help women to navigate 
this life transition with more comfort and less anxiety.

\section{Acknowledgements}

We would like to thank to PM Knauer for English editing.

Peer-review: Externally peer-reviewed.

Author Contributions:Concept MG, NE; Design MG, NE; Supervision MG, NE; Literature review MG, NE; Writing MG, NE; Critical review MG, NE.

Conflict of Interest: No conflict of interest was declared by the authors.

Financial Disclosure: The authors declared that this study hasn't received any financial support.

\section{References}

Aghamiri V, Mirghafourvand M, MohammadAlizadeh-Charandabi S, Nazemiyeh $H$. The effect of Hop (Humuluslupulus L.) on early menopausal symptoms and hot flashes: A randomized placebo-controlled trial. Complementary Ther Clin Pract 2015; 1-6. [Epub ahead of print]

Al-Akoum M, Maunsell E, Verreault R, Provencher L, Otis H, Dodin S. Effects of Hypericumperforatum (St. John's wort) on hot flashes and quality of life in perimenopausal women: a randomized pilot trial. Menopause 2009; 16: 307-14.

Atasü T, Şahmay S, editors. Jinekoloji. Second Edition. İstanbul: Nobel Tip Kitabevi; 2001.

Baksu A, Ayas B, Citak S, Kalan A, Baksu B, Goker N. Efficacy of tibolone and transdermal estrogen therapy on psychological symptoms in women following surgical menopause. Int $\mathbf{J}$ Gynaecol Obstet 2005; 9: 58-62.

Bezircioğlu I, Gülseren L, Öniz A, Kındıroğlu N. Depression-anxiety and disability in the Premenopausal and Postmenopausal Period. Turk Psikiyatri Derg 2004;15: 199-207.

Borelli F, Ernst E. Alternative and complementary therapies for the menopause. Maturitas 2010; 66: 333-43.

Borud EK, Alraek T, White A, Fonnebo V, Eggen AE, Hammar M, et al. The acupuncture on hot flushes among menopausal women (ACUFLASH) study, a randomized controlled trial. Menopause 2009; 16: 484-93.
Carmignani LO, Pedro AO, Costa-Paiva LH, PintoNeto AM. The effect of dietary soy supplementation compared to estrogen and placebo on menopausal symptoms: a randomized controlled trial. Maturitas 2010; 67: 262-69.

Mohammad-Alizadeh-Charandabi S, Shahnazi M, Nahaee J, Bayatipayan S. Efficacy of black cohosh (Cimicifugaracemosa L.) in treating early symptoms of menopause: a randomized clinical trial. Chin Med 2013; 8: 20.

Chedraui P, Pérez-López F, Sánchez H, Sánchez P, Miranda O, Quispe P, et al. Application of the 10-item Cervantes Scale among mid-aged Ecuadorian women for the assessment of menopausal symptoms. Maturitas 2014; 79: $100-5$

Egelioğlu N. Keten tohumu kullanımının menopozal semptomlar ve yaşam kalitesi üzerine etkisi. Izmir: Ege Üniversitesi Sağl1k Bilimleri Enstitüsü. 2012.

Elavsky S, Gonzales JU, Proctor DN, Williams N, Henderson VW. Effects of physical activity on vasomotor symptoms: examination using objective and subjective measures. Menopause 2012; 19: 1095-103.

Erkin Ö, Ardahan M, Kert A. Effect of Menopause on Women's Quality of Life. Gümüşhane University Journal of Health Sciences 2014; 3: 1095-113.

Ertem G. To determine the life quality of women in climacterium period. International Journal of Human Sciences 2010; 7: 469-83.

Hachul H, Garcia TKP, Maciel AL, Yagihara F, Tufik S, Bittencourt L. Acupuncture improves sleep in postmenopause in a randomized, double-blind, placebo-controlled study. Climacteric 2012; 16: 36-40.

Jackson HA, Sheehan AH. Effect of vitamin A on fracture risk. Ann Pharmacother 2005; 39: 208690.

Kal HE. Menopozal Dönemlerdeki Kadınlarda Uyku Sorunları ve İlişkili Faktörler. Konya: Selçuk Üniversitesi Sağlık Bilimleri Enstitüsü. 2011.

Kavlak T. Menopoz Dönemindeki Kadınlarda Kayg1 Düzeyleri Ve Cinsel Doyumun Saptanmas1. Ankara: Gazi Üniversitesi Sağl1k Bilimleri Enstitüsü. 2011. 
Koç Z, Sağlam Z. The Determination of The Symptom and The Attitudes of Women in Climacterium Period Related to Menopause. Aile ve Toplum Eğitim-Kültür ve Araştırma Dergisi 2008; 4: 100-12.

Kutlu R, Çivi S, Pamuk G. Postmenopozal Kadınlarda Osteoporoz Siklığı ve FRAXTM Skalası Kullanılarak 10 Yıllık Kırık Riskinin Hesaplanmasi. Turk J Phys Med Rehab 2012; 58:126-35.

Larmo PS., Yang B, Hyssälä J, Kallio HP, Erkkola R. Effects of sea buckthorn oil intake on vaginal atrophy in postmenopausal women: A randomized, double-blind, placebo-controlled study. Maturitas 2014; 79: 316-21.

Luoto R, Moilanen J, Heinonen R, Mikkola T, Raitanen J, Tomas E, et al. Effect of aerobic training on hot flushes and quality of life-a randomized controlled trial. Ann Med 2012; 44: 616-26.

Mansikkamäki K, Raitanen J, Nygård $\mathrm{CH}$, Heinonen R, Mikkola T, Luoto R. Sleep quality and aerobic training among menopausal women-A randomized controlled trial. Maturitas 2012; 72: 339-45.

Newton KM, Reed SD, Guthrie KA, Sherman KJ, Booth-LaForce C, Caan B, et al. Efficacy of yoga for vasomotor symptoms: a randomized controlled trial. Menopause 2014; 21: 339-46.

Nir Y, Huang MI, Schnyer R, Chen B, Manber R. Acupuncture for postmenopausal hot flashes. Maturitas 2007; 56: 383-95.

Oteroa U, Chorb D, Carvalhob M, Faersteinc E, Lopesc C, Werneckc G. Lack of association between age at menarche and age at menopause: Pró-Saúde Study, Rio de Janeiro, Brazil. Maturitas 2010; 67: 245-50.

Özcan H, Oskay Ü. Menopoz döneminde semptom yönetiminde kanıta dayalı uygulamalar. Göztepe Tip Dergisi 2013; 28:157-63.

Özkan S. Klimakteriyum ve Menopoz. Şirin A, Kavlak O, editors. Kadın Sağlığı. İstanbul: Nobel Tıp Kitabevi; 2015.
Özvarış ŞB, Metin BC, Dülger Ş, Eşme G, Tolunay GA, Zengin G, et al. Menopoz Dönemindeki Bir Grup Kadında Genel Sağlık Durumu ve Postmenopozal Yakınmaların Belirlenmesi. 17. Ulusal Halk Sağlı̆̆1 Kongresi; October, 20-24; Edirne- Turkey: 2014. p. 1102-3

Papadimitropoulos E, Wells G, Shea B, Gillespie W, Weaver B, Zytaruk N, et al. Meta-analyses of therapies for postmenopausal osteoporosis. VIII: Meta-analysis of the efficacy of vitamin D treatment in preventing osteoporosis in postmenopausal women. Endocr Rev 2002; 23: 560-9.

Petricevic L, Unger FM, Viernstein H, Kiss H. Randomized, double-blind, placebo-controlled study of oral lactobacilli to improve the vaginal flora of postmenopausal women. Eur J Obstet Gynecol Reprod Biol 2008; 141: 54-7.

Richy F, Schacht E, Bruyère O, Ethgen $O$, Gourlay M, Reginster JY. Vitamin D analogs versus native vitamin $\mathrm{D}$ in preventing bone loss and osteoporosis-related fractures: a comparative meta-analysis. Calcif Tissue Int 2005; 76: 17686.

Saka G, Ceylan A, Ertem M, Palanci Y, Toksöz P. Some Properties of Over 40 Years Women with High School and Over Regarding Menopausal Period and Conception of Calcium Source Foods in Diyarbakır. Dicle Tip Dergisi 2005; 32: 77-83.

Taavoni S, Ekbatani NN, Haghani $H$. Valerian/lemon balm use for sleep disorders during menopause. Complement Ther Clin Pract. 2013; 19: 193-96.

Taşkın L. Doğum ve Kadın Hastalığı Hemşireliği. Ankara: Akademisyen Kitabevi; 2015.

Turhan NO, Bolkan F, Duvan CI, Ardicoglu Y. The effect of isoflavones on bone mass and bone remodelling markers in postmenopausal women. Turk J Med Sci 2008; 38:145-52.

Young T, Rabago D, Zgierska A, Austin D, Laurel F. Objective and subjective sleep quality in premenopausal, perimenopausal, and postmenopausal women in the Wisconsin Sleep Cohort Study. Sleep 2003; 26: 667-72 